\title{
A novel alkaline protease with antiproliferative activity from fresh fruiting bodies of the toxic wild mushroom Amanita farinosa
}

\author{
Jian Sun', Yongchang Zhao'2, Hongmei Chai'2, Hexiang Wang ${ }^{1 凶}$ and Tzi Bun Ng ${ }^{3 凶}$ \\ 1State Key Laboratory for Agrobiotechnology and Department of Microbiology, China Agricultural University, Beijing, China; 2Institute of Bio- \\ technology and Germplasmic Resource, Yunnan Academy of Agricultural Science, Kunming, China; ${ }^{3}$ School of Biomedical Sciences, Faculty of \\ Medicine, The Chinese University of Hong Kong, Shatin, New Territories, Hong Kong, China
}

\begin{abstract}
A novel protease with a molecular mass of $15 \mathrm{kDa}$ was purified from fresh fruiting bodies of the wild mushroom Amanita farinosa. The purification protocol entailed anion exchange chromatography on DEAE-cellulose, affinity chromatography on Affi-gel blue gel, cation exchange chromatography on SP-Sepharose, and gel filtration by fast protein liquid chromatography on Superdex 75. The protease was unadsorbed on DEAE-cellulose but adsorbed on Affi-gel blue gel and SP-Sepharose. It demonstrated a single $15-\mathrm{kDa}$ band in sodium dodecyl sulfate-polyacrylamide gel electrophoresis (SDS/ PAGE) and a 15-kDa peak in gel filtration. The optimal $\mathrm{pH}$ and optimal temperature of the protease were $\mathrm{pH}$ 8.0 and $65^{\circ} \mathrm{C}$, respectively. Proliferation of human hepatoma HepG2 cells was inhibited by the protease with an $I_{50}$ of $25 \mu \mathrm{M}$. The protease did not have antifungal or ribonuclease activity.
\end{abstract}

Keywords: alkaline protease; Amanita farinosa; mushroom; fruiting bodies; antiproliferative; purification

Received: 10 May, 2011; revised: 18 August, 2011; accepted: 05 December, 2011; avalable on-line: 06 December, 2011

\section{INTRODUCTION}

Mushrooms are components of popular dishes in Oriental as well as Western cuisine. This is not only due to their delicious taste, but also because of their extensive nutritive value. Nowadays, with more and more people paying close attention to issues related to health, many investigators show interest in the highly nutritive mushrooms.

Mushrooms are abundant in proteins which have beneficial effects. To date, mushroom proteins have been purified and characterized including ribosome inactivating proteins (Wang \& Ng, 2000a; Lam \& Ng, 2001a, 2001b; Wang \& Ng, 2001a; Ng \& Wang, 2004a; 2004b), antifungal proteins (Lacadena et al., 1995; Lam \& Ng, 2001a; Wang \& Ng, 2004; Guo et al., 2005), ribonucleases (Wang \& Ng, 2001c; Wang \& Ng, 2003a, 2003b), ubiquitin-like proteins and peptides (Wang \& $\mathrm{Ng}$, 2000b; Wang et al., 2003b), lectins (Wang et al., 2002; Wang et al., 2003a; Liu et al., 2004), proteases (Sattar et al., 1990; Nonaka et al., 1995), cellulases (Teunissen \& Op den Camp, 1993), xylanases (Kutasi et al., 2001), laccases (Slomczynski et al., 1995), invertases (Boddy et al., 1993), and trehalose phosphorylases (Wannet et al., 1998). Many of these proteins have applicable activities because of their functions like antiproliferative activity toward tumor cells (Wang et al., 1995; Ngai \& Ng, 2004), antitumor activity (Wang et al., 2000; Sun et al., 2010), mitogenic activity toward spleen cells (Wang et al., 2002; Ngai \& Ng, 2004), and inhibitory activity toward HIV-1 reverse transcriptase (Wang \& $\mathrm{Ng}, 2001 \mathrm{c}$ ).

The objective of this paper was to purify a protease from the wild mushroom Amanita farinosa and ascertain its characteristics to find out whether it has any potentially useful activities.

Many mushroom of the Amanita genus are toxic, e.g., A. excelsa, A. farinosa, A. phalloides, A. psendoporphyria, A. spissa, $A$. spreta and $A$ spissacea. Very few can be consumed without intoxication, e.g., $A$. rubescens and A. viryenefides are edible (Chang \& Mao, 1995).

\section{MATERIALS AND METHODS}

Materials. Fruiting bodies of the mushroom Amanita farinosa were collected in the Yunnan Province in China. DEAE-cellulose was from Sigma Chemical Company, St. Louis, Missouri, USA. Affi-gel blue gel was from BioRad, California, USA. SP-Sepharose and Superdex 75 HR 10/30 column were from GE Healthcare, Sweden. HepG2 cell line was purchased from American Type Culture Collection [ATCC], Manassas, USA. All other chemicals used were of analytical grade.

Isolation procedure. Fresh fruiting bodies of the wild mushroom $A$. farinosa $(240 \mathrm{~g})$ were extracted by homogenizing in distilled water $(3 \mathrm{ml} / \mathrm{g})$ at $4{ }^{\circ} \mathrm{C}$ for 12 h. The homogenate was centrifuged at $14000 \times g$ for 25 min at $4{ }^{\circ} \mathrm{C}$. The supernatant was chromatographed on a column of DEAE-cellulose $(5 \mathrm{~cm} \times 10 \mathrm{~cm})$, which had previously been equilibrated and was then eluted with $10 \mathrm{mM}$ Tris/ $\mathrm{HCl}$ buffer ( $\mathrm{pH}$ 7.4). After removal of the unadsorbed fraction D1, adsorbed materials were eluted with $0.2 \mathrm{M} \mathrm{NaCl}$ and then with $1 \mathrm{M} \mathrm{NaCl}$ in the same buffer to yield fractions D2 and D3, respectively. Fraction D1 with protease activity was next subjected to a column of Affi-gel blue gel $(2.5 \mathrm{~cm} \times 20 \mathrm{~cm})$ in the same buffer. The column was eluted at a flow rate of 2 $\mathrm{ml} / \mathrm{min}$. After the first unadsorbed fraction had flowed through the column, adsorbed proteins were desorbed

\section{Email: hxwang@cau.edu.cn}

Abbreviations: FPLC, fast protein liquid chromatography; PMSF, phenylmethylsulfonyl fluoride; EDTA, ethylenediaminetetraacetic acid. 
using a linear (0-1 M) NaCl gradient. Protease activity found in the adsorbed fraction (B2) was further purified by chromatography on an SP-Sepharose column $(2.5 \times 20 \mathrm{~cm})$ in $10 \mathrm{mM} \mathrm{NaOAc}$ buffer $(\mathrm{pH} 4.8)$. The active fraction (SP4) was eluted with a linear 0-1 $\mathrm{M} \mathrm{NaCl}$ gradient. Fraction SP4 was subsequently fractionated on an FPLC-Superdex $75 \mathrm{HR} 10 / 30$ column in $0.2 \mathrm{M}$ $\mathrm{NH}_{4} \mathrm{HCO}_{3}$ buffer (pH 8.5) (Ngai \& Ng, 2004).

SDS/polyacrylamide gel electrophoresis (SDS/ PAGE). SDS/PAGE was carried out in accordance with the procedure of Laemmli (1970), using a 12\% resolving gel and a $5 \%$ stacking gel. At the end of electrophoresis, the gel was stained with Coomassie Brilliant Blue.

Amino acid sequence analysis. The N-terminal sequence of the protease was determined by using a Hewlett-Packard HP G1000A Edman degradation unit and an HP 1000 HPLC System.

Assay for proteolytic activity of Amanita farino$\boldsymbol{s} \boldsymbol{a}$ protease. The activity of the purified protease toward casein (Sigma) was assayed following the method of Wang and $\mathrm{Ng}$ (2001b). The concentration of casein was $1 \mathrm{mg} / \mathrm{ml}$ in $10 \mathrm{mM}$ phosphate buffer ( $\mathrm{pH} \mathrm{7.2).} \mathrm{The}$ sample $(20 \mu \mathrm{l})$ was incubated with $180 \mu \mathrm{l}$ casein solution at $37^{\circ} \mathrm{C}$ for 15 minutes. The reaction was terminated by addition of $400 \mu \mathrm{l}$ of $5 \%$ trichloroacetic acid (TCA). Then the sample was centrifuged $(12000 \times \mathrm{g}$, $\left.5 \mathrm{~min}, 4^{\circ} \mathrm{C}\right)$. Absorbance of the surpernatant was read at $280 \mathrm{~nm}$ against water as blank. Protease activity was expressed in units, where one unit represented a 0.001 absorbance increase per minute in the supernatant per $\mathrm{ml}$ of reaction mixture under specified conditions (Wang $\& \mathrm{Ng}, 2001 \mathrm{~b})$.

Effect of $\mathrm{pH}$ on protease activity. The effect of $\mathrm{pH}$ in the range of 3 to 9 was tested. The buffers used to cover the $\mathrm{pH}$ range were $0.1 \mathrm{M} \mathrm{NaOAc}$ buffer (AA) ( $\mathrm{pH}$ 3-4), 0.1 M Mes buffer ( $\mathrm{pH}$ 4-7), and 0.1 M Hepes buffer (pH 7-9). A. farinosa protease was kept in buffer solutions at different $\mathrm{pH}$ values for $15 \mathrm{~min}$ at $37^{\circ} \mathrm{C}$. Then the protease activity was determined.

Effect of temperature on protease activity. Samples of the protease were kept at several different temperatures $\left(20^{\circ} \mathrm{C}\right.$ to $100^{\circ} \mathrm{C}$ at $10^{\circ} \mathrm{C}$ intervals) for 15 min. The reaction was carried out at the optimum $\mathrm{pH}$ $(\mathrm{pH})$. After that, protease activity was determined. The temperature at which enzyme activity was maximal was the optimum temperature (Lam \& Ng, 2001b).

Tumor cell viability assay. HepG2 cells were cultured in RPMI medium supplemented with $10 \%$ $(\mathrm{v} / \mathrm{v})$ fetal bovine serum (FBS), $100 \mathrm{mg} / 1$ streptomycin, and $100 \mathrm{IU} / \mathrm{ml}$ penicillin, at $37^{\circ} \mathrm{C}$ in a humidified atmosphere of $5 \%(\mathrm{v} / \mathrm{v}) \mathrm{CO}_{2}$. Cells were subsequently seeded into 96 -well plates at a concentration of $2 \times 10^{3}$ cells/well, and incubated for $24 \mathrm{~h}$. Different concentrations of the protease in $100 \mu \mathrm{l}$ complete RPMI medium were then added to the wells and incubated for $72 \mathrm{~h}$ (Wang et al., 1995). After that, MTT quantification assays were carried out to measure the cells' viability. Briefly, $20 \mu \mathrm{l}$ of a $5 \mathrm{mg} / \mathrm{ml}$ solution of [3-[4,5-dimethythiazol-2-yl]-2,5-diphenyltetrazolium bromide] (MTT) in phosphate buffered saline was spiked into each well, and the plates were incubated for $4 \mathrm{~h}$. The plates were then centrifuged at 2500 r.p.m. for $5 \mathrm{~min}$. The supernatant was carefully removed, and $150 \mu \mathrm{l}$ of dimethyl sulfoxide was added in each well to dissolve the MT'T formazan at the bottom of the wells. After $10 \mathrm{~min}$, the absorbance at $590 \mathrm{~nm}$ was measured with a microplate reader. PBS was added into wells instead of protease as control.
Assay of antifungal activity. The assay for antifungal activity toward Rhizoctonia solani, and other fungal species, Sclerotinia sclerotiorum, R. cerealis, and Fusarium oxysporum, was carried out in $90 \times 15 \mathrm{~mm}$ Petri plates containing $10 \mathrm{ml}$ of potato dextrose agar. After the mycelial colony had developed, sterile blank paper disks $(0.625 \mathrm{~cm}$ in diameter) were placed at a distance of $0.5 \mathrm{~cm}$ away from the rim of the mycelial colony. An aliquot $(15 \mu \mathrm{l})$ of the test sample was added to a disk. The plates were incubated at $23^{\circ} \mathrm{C}$ for $72 \mathrm{~h}$ until mycelial growth had enveloped disks containing the control and had formed crescents of inhibition around disks containing samples with antifungal activity (Lacadena et al., 1995).

Assay of ribonuclease activity. Yeast tRNA (Sigma) was used as substrate. Protease was incubated with 0.2 $\mu \mathrm{g}$ tRNA in $135 \mu \mathrm{l}$ of $100 \mathrm{mM}$ sodium phosphate buffer (pH 7.5) for $15 \mathrm{~min}$. Then, $350 \mu \mathrm{l}$ ice-cold 3.7\% perchloric acid was added to terminate the reaction. After standing on ice for $15 \mathrm{~min}$, the reaction mixture was centrifuged and the absorbance of the supernatant was $\mathrm{read}$ at $260 \mathrm{~nm}$. One unit of ribonuclease activity is defined as the amount of enzyme that produces an absorbance increase of one per minute in the acid-soluble supernatant per milliter of reaction mixture under specified conditions (Wang \& Ng, 2003a).

Assay for HIV-1 reverse transcriptase inhibitory activity. The inhibitory activity towards human immunodeficiency virus type $1(\mathrm{HIV}-1)$ reverse transcriptase (RT) was assessed by using an enzyme-linked immunosorbent assay (ELISA) kit from Boehringer Mannheim (Germany). The assay takes advantage of the ability of reverse transcriptase to synthesize DNA, starting from the template/primer hybrid $\operatorname{poly}(\mathrm{A})$-oligo(dT) ${ }_{15}$. Digoxigenin- and biotin-labeled nucleotides in an optimized ratio are incorporated into the DNA molecule synthesized by the RT. The detection and quantification of the synthesized DNA as a measure of RT activity follows sandwich ELISA protocol. A fixed amount (4-6 ng) of recombinant HIV-1 RT was used. The inhibitory activity of the protease was calculated as percent inhibition as compared to a control without the protein (Sun et al., 2011).

\section{RESULTS}

\section{Purification of Amanita farinosa protease}

When the Amanita farinosa fruiting body extract was fractionated on DEAE-cellulose, the unadsorbed fraction D1 possessed protease activity whereas the adsorbed fractions D2 and D3 had no discernible activity. D1 was resolved by affinity chromatography on Affi-gel blue gel into an unadsorbed fraction B1 devoid of protease activity and an adsorbed fraction B2 with protease activity. When fraction B2 was chromatographed on SP- Sepharose, only the fourth fraction SP4 eluted by a linear 0-1 M NaCl gradient exhibited protease activity (Fig. 1). It was then separated by gel filtration on Superdex 75 into a smaller inactive fraction SU1 and a larger fraction SU2 with protease activity (Fig. 2). The molecular mass of SU2 was determined to be $15 \mathrm{kDa}$, as judged from its elution volume. This result was similar to that obtained from SDS/polyacrylamide gel electrophoresis (Fig. 3), in which the protease exhibited a single 15 $\mathrm{kDa}$ band. The yields and specific protease activities at the various stages of purification are shown in Table 1. The N-terminal amino acid sequence of the protease was 


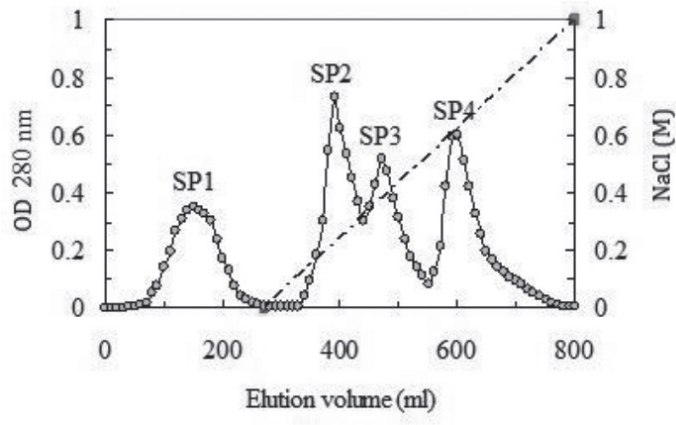

Figure 1. Ion exchange chromatography on SP-Sepharose. Sample: fraction of Amanita farinosa fruiting body extract previously unadsorbed on DEAE-cellulose (fraction D1) and subsequently adsorbed on Affi-gel blue gel (fraction B2). Column dimensions: $2.5 \mathrm{~cm} \times 20 \mathrm{~cm}$. Starting buffer: $10 \mathrm{mM}$ NaOAc $(\mathrm{pH}$ 4.8). Slanting dotted line across the right half of the chromatogram represents a linear $0-1 \mathrm{M} \mathrm{NaCl}$ gradient used to elute adsorbed proteins. Protease activity was located in fraction SP4.

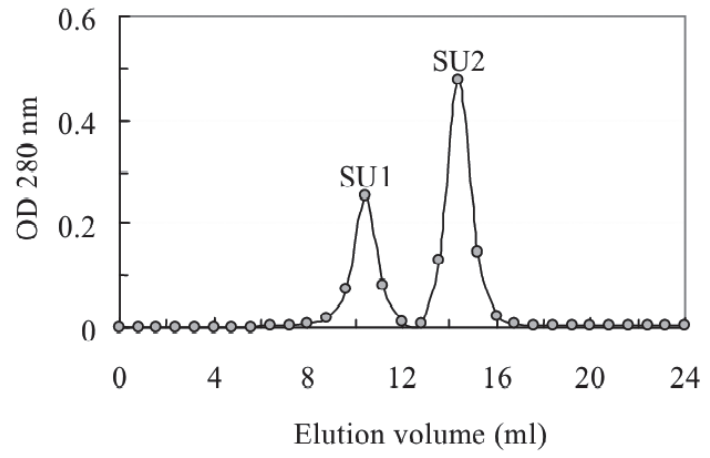

Figure 2. Gel filtration of fraction SP4 on a Superdex 75 HR $10 / 30$ column by fast protein liquid chromatography.

Buffer: $0.2 \mathrm{M} \mathrm{NH}_{4} \mathrm{HCO}_{3}$ buffer $(\mathrm{pH}$ 8.5). Flow rate: $0.4 \mathrm{ml} / \mathrm{min}$. Peak SU2 represents purified Amanita farinosa protease. Protease activity was located in fraction SU2.

VFDESAGQGT. It exhibited some similarity in $\mathrm{N}$-terminal sequence to the protease from another Agaricales mushroom, Pleurotus citrinopileatus. However, there was little resemblance to a protease from Agaricus bisporus, also belonging to Agaricales (Table 2).

\section{Characterization of Amanita farinosa protease}

The $\mathrm{pH}$ dependence of the protease activity toward casein is shown in Fig. 4. The activity rose steadily when the $\mathrm{pH}$ was elevated from 3 to 8 , and fell when the $\mathrm{pH}$ was raised beyond 8 . The enzyme activity rose over the temperature range $20-65^{\circ} \mathrm{C}$ (Fig. 5). The optimal $\mathrm{pH}$ and optimal temperature were $\mathrm{pH} 8$ and $65^{\circ} \mathrm{C}$, respectively. Table 3 shows the viability of HepG2 cells after incubation with different concentrations of Amanita farinosa protease for $72 \mathrm{~h}$. The inhibitory activity of the protease was dose-dependent. When the protease concentration was $100 \mu \mathrm{M}$, the inhibition ratio achieved was $63.9 \%$. The activity of purified protease was inhibited by PMSF ( $3 \%$ residual activity with $1 \mathrm{mM}$ PMSF), but not by EDTA or pepstatin A, which may be an indication that the enzyme belongs to the serine protease family. Antifungal, ribonuclease, HIV-1 reverse transcriptase inhibitory activities were undetectable for the protease (data not shown). Table 4 shows a comparison of Amanita farinosa protease and $P$. citrinopileatus protease. Both are monomeric alkaline proteases with similar

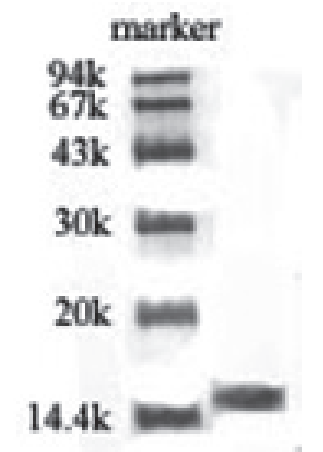

Figure 3. Sodium dodecyl sulfate-polyacrylamide gel electrophoresis.

Right lane: Amanita farinosa protease $(10 \mu \mathrm{g})$. Left lane: molecular mass standards, from top downward: phosphorylase b (94 $\mathrm{kDa})$, bovine serum albumin $(67 \mathrm{kDa})$, ovalbumin $(43 \mathrm{kDa})$, carbonic anhydrase (30 kDa), soybean trypsin inhibitor (20 kDa), and a-lactalbumin (14.4 kDa).

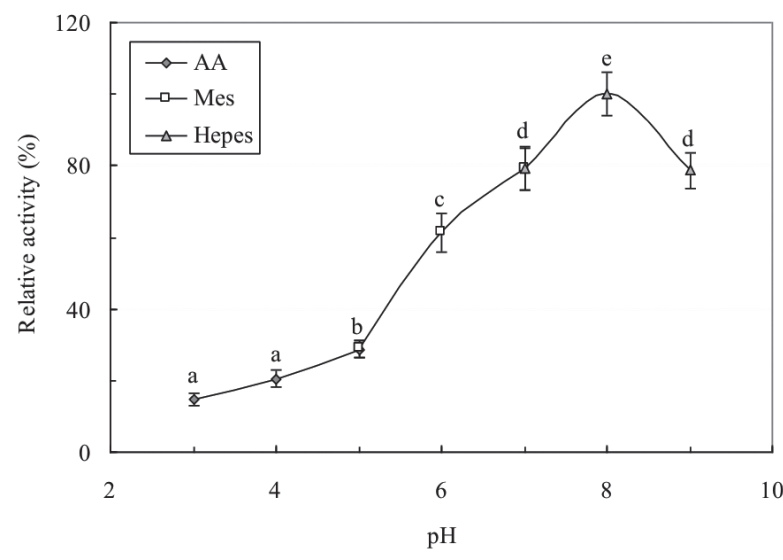

Figure 4. $\mathrm{pH}$ dependence of Amanita farinosa protease.

Temperature used: $37^{\circ} \mathrm{C}$, maximum activity $=100 \%$. Results are presented as mean \pm S.D. $(n=3)$. Different letters $(a, b$, c etc) indicate statistically significant difference $(p<0.05)$ when the data are analyzed by analysis of variance followed by Duncan's multiple range test.

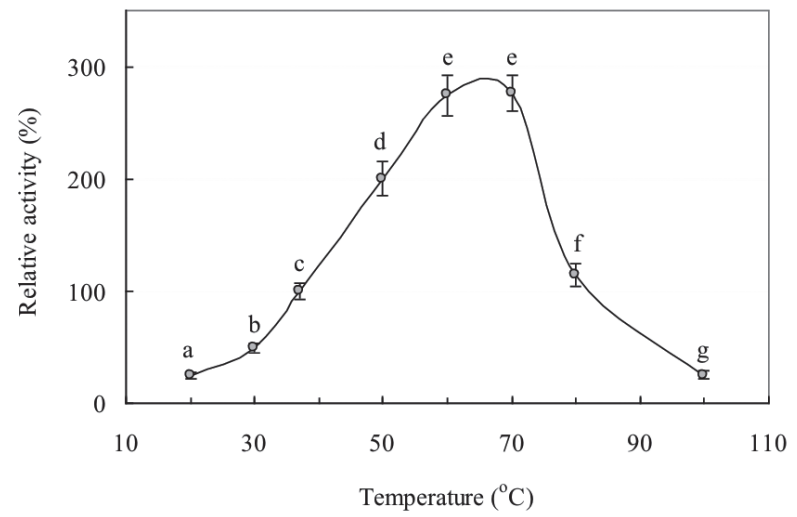

Figure 5. Effect of temperature on activity of Amanita farinosa protease.

Reaction time: 15 min. Substrate: casein. Buffer: $0.1 \mathrm{M}$ Hepes buffer (pH 8.0). The activity at $37^{\circ} \mathrm{C}$ used as reference was considered to be $100 \%$. Results are presented as mean \pm S.D. $(n=3)$. Different letters ( $a, b, c$ etc) indicate statistically significant difference $(p<0.05)$ when the data are analyzed by analysis of variance followed by Duncan's multiple range test. 
Table 1. Yields and protease activities of various chromatographic fractions (from $240 \mathrm{~g}$ fresh fruiting bodies).

\begin{tabular}{llll}
\hline $\begin{array}{l}\text { Chromatographic } \\
\text { fraction }\end{array}$ & Yield (mg) & $\begin{array}{l}\text { Specific protease } \\
\text { activity }(\mathrm{U} / \mathrm{mg})\end{array}$ & $\begin{array}{l}\text { Purification } \\
\text { fold }\end{array}$ \\
\hline Extract & 830.1 & 180.5 & 1 \\
D1 & 241.6 & 437.7 & 2.4 \\
D2 & 155.0 & $<10$ & - \\
D3 & 190.2 & $<10$ & - \\
B1 & 83.9 & $<10$ & - \\
B2 & 52.7 & 1422.0 & 7.9 \\
B3 & 39.5 & $<10$ & - \\
SP1 & 8.7 & $<10$ & - \\
SP2 & 11.4 & $<10$ & - \\
SP3 & 8.2 & 231.3 & 1.3 \\
SP4 & 9.3 & 5759.5 & 31.9 \\
SU1 & 2.2 & 260.2 & 1.4 \\
SU2 & 4.1 & 9200.0 & 51.0 \\
\hline
\end{tabular}

Table 2. N-terminal sequence of Amanita farinosa protease compared to other fungal alkaline proteases (Results of BLAST search). Identical corresponding amino acid residues are underscored.

\begin{tabular}{lll}
\hline Species & Phylum & $\begin{array}{l}\text { N-terminal se- } \\
\text { quence }\end{array}$ \\
\hline Amanita farinosa & Basidiomycota & VFDESAGQGT \\
Pleurotus citrinopileatus & Basidiomycota & VCQCNAPWGL \\
Agaricus bisporus & Basidiomycota & MHFSLSFATL \\
Cordyceps chlamydosporia & Ascomycota & AIVEQQGAPW \\
Paecilomyces lilacinus & Ascomycota & ARAPLLTPRG \\
Penicillium chrysogenum & Ascomycota & MGFLKLLSTS \\
Aspergillus oryzae & Ascomycota & MQSIKRTLLL \\
\hline
\end{tabular}

Table 3. Inhibition of proliferation of HEPG2 cells by Amanita farinosa protease as determined by MTT assay.

PBS was used in the control instead of the protease.

\begin{tabular}{ll}
\hline $\begin{array}{l}\text { Protease } \\
\text { concentration }(\mu \mathrm{M})\end{array}$ & $\begin{array}{l}\text { Inhibition of cell } \\
\text { proliferation(\%) }\end{array}$ \\
\hline 100 & 63.9 \\
50 & 57.6 \\
25 & 50.0 \\
12.5 & 38.9 \\
6.2 & 32.0 \\
3.1 & 26.3 \\
1.6 & 21.2 \\
\hline
\end{tabular}

Each value is the mean for triplicate determinations, with an S.D. less than $10 \%$.

chromatographic behavior on ion exchangers and slightly similar N-terminal amino acid sequences.

\section{DISCUSSION}

An alkaline protease with a molecular mass of $15 \mathrm{kDa}$ was isolated from fresh fruiting bodies of the wild mushroom Amanita farinosa. Its N-terminal amino acid sequence was VFDESAGQGT. Compared with the reported proteases or metalloproteases from other mushrooms, its molecular mass is smaller than those from Armillariella mellea (Kim \& Kim, 1999), Grifola frondosa, Pleurotus ostreatus (Nonaka et al., 1997), and Tricholoma saponaceum (Kim \& Kim, 2001), which are in the range from 18.5 to $20 \mathrm{kDa}$. However, the molecular mass of the $A$. farinosa protease is a little larger than that of pleureryn from Pleurotus eryngii, which has a molecular mass $11.5 \mathrm{kDa}(\mathrm{Kim} \& \mathrm{Kim}, 2001)$.

The optimal $\mathrm{pH}$ of the protease from $A$. farinosa was $\mathrm{pH}$ 8. It indicated that this protease was an alkaline protease. When the $\mathrm{pH}$ was raised to 9, close to $80 \%$ of the activity of the protease was preserved. However, only about one-fifth of the activity was retained at $\mathrm{pH} 4$. The activity of the $A$. farinosa protease reached the maximum at $65^{\circ} \mathrm{C}$ and at $\mathrm{pH} 8$. However, its activity showed a precipitous decline as the temperature was raised from $70^{\circ} \mathrm{C}$ to $80^{\circ} \mathrm{C}$. Thus, it was a moderately thermostable protease. The $A$. farinosa protease exhibits a higher optimal $\mathrm{pH}$ and a higher optimal temperature than some reported mushroom proteases (Kim et al., 2006; Park et al., 2007; Shen et al., 2007).

It has long been known that chemical drugs can induce numerous side effects and cytotoxicity when used for the treatment of cancer. In an attempt to tackle this problem, scientists are now searching for materials with lower cytotoxicity and fewer side effects than chemical drugs. In fact, natural products such as those from mushrooms are good choices for replacement of toxic drugs as they are used widely in Chinese medicine. Abundant resources also exist in mushrooms which exhibit a multitude of biological activities (Nonaka et al., 1997).

It has been reported that many mushroom lectins display antiproliferative activities toward tumor cells. However, no antiproliferative activity of mushroom proteases has been reported. The isolated protease demonstrated an anti-tumor activity toward HepG2 cells with an $\mathrm{IC}_{50}$ of about $25 \mu \mathrm{M}$, which represents a fairly potent activity. It is well known that some proteases like caspases play a role in the apoptotic death of tumor cells (Puertollano et al., 2008). On the other hand, protease inhibitors like those of leguminous origin (Banerji et al., 1998) have antitumor activity.

A protease (Nygren et al., 2007), a protease inhibitor (Doljak et al., 2001), a hemolysin (Seeger, 1977), and a lectin (Zhuang et al., 1996) have been isolated from Amanita spp. No proteins have been purified from Amanita farinosa. The present study thus adds to the scanty literature. We have assayed the fruiting body extract of $A$. farinosa for hemagglutinating (lectin), antifungal and ribonuclease activities. The negative results indicate the absence of those bioactive proteins in $A$. farinosa.

Proteases are a class of enzymes with important applications in industrial fields, such as in the food, detergent, leather, pharmaceutical, and silk industries and for recovery of silver from used X-ray films (Sattar et al., 1990; Nonaka et al., 1995; Nygren et al., 2007). Thirty percent of the total enzymes produced in the world are proteases (in detergent industries). Besides industrial applications, proteases play important physiological roles in sporulation, conidial discharge, germination, enzyme modification, nutrition, protein turnover, and regulation of gene expression (Rao et al., 1998). The A. farinosa protease may have similar roles in the mushroom. In addition, 
Table 4. Comparison of characteristics of proteases from Amanita farinosa and Pleurotus citrinopileatus.

\begin{tabular}{|c|c|c|}
\hline & Amanita farinosa protease & P. citrinopileatus protease \\
\hline Chromatographic behavior on anion exchangers & unadsorbed & unadsorbed \\
\hline Chromatographic behavior on cation exchangers & adsorbed & adsorbed \\
\hline Purification fold & 51 & 30 \\
\hline Yield (mg/kg) & 17 & 29 \\
\hline $\mathrm{N}$-terminal sequence & VFDESAGQGT & VCQCNAPWGL \\
\hline Molecular mass (kDa) & 15 & 28 \\
\hline Mornomeric & Yes & Yes \\
\hline Specific protease activity $(\mathrm{u} / \mathrm{mg})$ & 9200 & 14526 \\
\hline Optimum pH & 8 & 10 \\
\hline Optimum temperature $\left({ }^{\circ} \mathrm{C}\right)$ & 65 & 50 \\
\hline $\begin{array}{l}\text { Anti-proliferative activity } \\
\text { on hepatoma cells }\end{array}$ & $\mathrm{IC}_{50}=25 \mu \mathrm{M}$ & Not tested \\
\hline
\end{tabular}

Table 5. Influence of inhibitors on $A$. farinose protease.

\begin{tabular}{lll}
\hline Chemical & Concentration & Residual activity (\%) \\
\hline None & & $100 \%$ \\
\hline PMSF & $1 \mathrm{mM}$ & $3 \%$ \\
& $0.2 \mathrm{mM}$ & $22 \%$ \\
& $0.04 \mathrm{mM}$ & $70 \%$ \\
\hline Pepstatin A & $1 \mathrm{mM}$ & $88 \%$ \\
& $0.2 \mathrm{mM}$ & $89 \%$ \\
& $0.04 \mathrm{mM}$ & $100 \%$ \\
\hline EDTA & $1 \mathrm{mM}$ & $93 \%$ \\
& $0.2 \mathrm{mM}$ & $96 \%$ \\
\hline
\end{tabular}

Each residual activity is the mean for triplicate determinations, with an S.D. less than $10 \%$.

the protease may act as a defense protein by hydrolyzing proteins of invading pathogens.

To recapitulate, an alkaline protease with relatively high thermostability and $\mathrm{pH}$ stability and potent antiproliferative activity against hematoma cells was isolated from a wild mushroom of which little is known.

\section{Acknowledgements}

This work was financially supported by National Grants of China (nyhyzx07-008, 2007BAD89B00 and 2010CB732202).

\section{REFERENCE}

Banerji A, Fernandes A, Bane S (1998) Treatment with field bean protease inhibitor can effectively repress ethylnitrosourea (ENU)induced neoplasms of the nervous system in Sprague-Dawley rats. Cancer Lett 130: 161-167.

Boddy LM, Berges T, Barreau C, Vainstein MH, Dobson MJ, Ballance DJ, Peberdy JF (1993) Purification and characterisation of an $A s$ pergillus niger invertase and its DNA sequence. Curr Genet 24: 60-66.

Chang ST, Mao XL (1995) Hong Kong Mushrooms. Chinese University of Hong Kong Press. Hong Kong.

Doljak B, Stegnar M, Urleb U, Kreft S, Umek A, Ciglaric M, Strukelj B, Popovic T (2001) Screening for selective thrombin inhibitors in mushrooms. Blood Coagul Fibrinolysis 12: 123-128.
Guo Y, Wang H, Ng TB (2005) Isolation of trichogin, an antifungal protein from fresh fruiting bodies of the edible mushroom Tricboloma giganteum. Peptides 26: 575-580.

Kim JH, Kim YS (1999) A fibrinolytic metalloprotease from the fruiting bodies of an edible mushroom, Armillariella mellea. Biosci Biotechnol Biochem 63: 2130-2136.

Kim JH, Kim YS (2001) Characterization of a metalloenzyme from a wild mushroom, Tricholoma saponaceum. Biosci Biotecbnol Biochem 65: 356-362.

Kim JS, Sapkota K, Park SE, Choi BS, Kim S, Nguyen TH, Kim CS, Choi HS, Kim MK, Chun HS, Park Y, Kim SJ (2006) A fibrinolytic enzyme from the medicinal mushroom Cordyceps militaris. J Microbiol 44: 622-631.

Kutasi J, Bata A, Brydl E, Rafai P, Jurkovich V (2001) Characterisation and effects of a xylanase enzyme preparation extracted from Thermomyces lanuginosus cultures. Acta Vet Hung 49: 175-184.

Lacadena J, Martinez del Pozo A, Gasset M, Patino B, Campos-Olivas R, Vazquez C, Martinez-Ruiz A, Mancheno JM, Onaderra M, Gavilanes JG (1995) Characterization of the antifungal protein secreted by the mould Aspergillus giganteus. Arch Biochem Biophys 324: 273-281.

Laemmli UK (1970) Cleavage of structural proteins during the assembly of the head of bacteriophage T4. Nature 227: 680-685.

Lam SK, Ng TB (2001a) First simultaneous isolation of a ribosome inactivating protein and an antifungal protein from a mushroom (Lyophyllum shimejz) together with evidence for synergism of their antifungal effects. Arch Biochem Biophys 393: 271-280.

Lam SK, Ng TB (2001b) Hypsin, a novel thermostable ribosome-inactivating protein with antifungal and antiproliferative activities from fruiting bodies of the edible mushroom Hypsizigus marmoreus. Biochem Biophys Res Commun 285: 1071-1075.

Liu Q, Wang $\mathrm{H}, \mathrm{Ng}$ TB (2004) Isolation and characterization of a novel lectin from the wild mushroom Xerocomus spadiceus. Peptides 25: $7-10$.

$\mathrm{Ng}$ TB, Wang H (2004a) Adustin, a small translation-inhibiting polypeptide from fruiting bodies of the wild mushroom Polyporus adusta. Peptides 25: 689-692.

$\mathrm{Ng}$ TB, Wang HX (2004b) Flammin and velin: new ribosome inactivating polypeptides from the mushroom Flammulina velutipes. Peptides 25: 929-933.

Ngai PH, Ng TB (2004) A mushroom (Ganoderma capense) lectin with spectacular thermostability, potent mitogenic activity on splenocytes, and antiproliferative activity toward tumor cells. Biochem Biophys Res Commun 314: 988-993.

Nonaka T, Dohmae N, Hashimoto Y, Takio K (1997) Amino acid sequences of metalloendopeptidases specific for acyl-lysine bonds from Grifola frondosa and Pleurotus ostreatus fruiting bodies. J Biol Chem 272: 30032-30039.

Nonaka T, Ishikawa $\mathrm{H}$, Tsumuraya $\mathrm{Y}$, Hashimoto $\mathrm{Y}$, Dohmae N (1995) Characterization of a thermostable lysine-specific metalloendopeptidase from the fruiting bodies of a basidiomycete, Grifola frondosa. J Biochem 118: 1014-1020.

Nygren CM, Edqvist J, Elfstrand M, Heller G, Taylor AF (2007) Detection of extracellular protease activity in different species and genera of ectomycorrhizal fungi. Mycorrbiza 17: 241-248.

Park SE, Li MH, Kim JS, Sapkota K, Kim JE, Choi BS, Yoon YH, Lee JC, Lee HH, Kim CS, Kim SJ (2007) Purification and characterization of a fibrinolytic protease from a culture supernatant of Flammulina velutipes mycelia. Biosci Biotechnol Biochem 71: 2214-2222. 
Puertollano MA, Carrera MP, Puertollano E, Alvarez de Cienfuegos G, Ramirez-Exposito MJ, De Pablo MA, Martinez-Martos JM (2008) Analysis of caspase activities in rat mammary tumours induced by N-methyl-nitrosourea. Oncol Rep 20: 657-662.

Rao GS, Arora S, Kataria S (1998) A proteinase K inhibitor using alpha,beta-unsaturated (dehydro) residues: a presumptive model. J Biomol Struct Dyn 15: 1053-1058.

Sattar AK, Yamamoto N, Yoshimoto T, Tsuru D (1990) Purification and characterization of an extracellular prolyl endopeptidase from Agaricus bisporus. J Biochem 107: 256-261.

Seeger R (1977) Hemolysins in mushrooms of the genus Amanita. Curr Probl Clin Biochem 7: 15-21.

Shen MH, Kim JS, Sapkota K, Park SE, Choi BS, Kim S, Lee HH, Kim CS, Chun HS, Ryoo CI, Kim SI (2007) Purification, characterization, and cloning of fibrinolytic metalloprotease from Pleurotus ostreatus mycelia. J Microbiol Biotechnol 17: 1271-1283.

Slomczynski D, Nakas JP, Tanenbaum SW (1995) Production and Characterization of Laccase from Botrytis cinerea 61-34. Appl Environ Microbiol 61: 907-912.

Sun J, Wang H, Ng TB (2010) Trypsin isoinhibitors with antiproliferative activity toward leukemia cells from Phaseolus vulgaris cv "White Cloud Bean". I Biomed Biotechnol 2010: 219793.

Sun J, Wang HX, Ng TB (2011) Isolation of a laccase with HIV-1 reverse transcriptase inhibitory activity from fresh fruiting bodies of the Lentinus edodes (Shiitake mushroom). Indian J Biochem Biophys 48: 88-94.

Teunissen MJ, Op den Camp HJ (1993) Anaerobic fungi and their cellulolytic and xylanolytic enzymes. Antonie Leeuwenhoek 63: 63-76.

Wang H, Gao J, Ng TB (2000) A new lectin with highly potent antihepatoma and antisarcoma activities from the oyster mushroom Pleurotus ostreatus. Biochem Biophys Res Commun 275: 810-816.

Wang $\mathrm{H}, \mathrm{Ng} \mathrm{TB}$ (2001a) Isolation and characterization of velutin, a novel low-molecular-weight ribosome-inactivating protein from winter mushroom (Flammulina velutipes) fruiting bodies. Life Sci 68: 2151-2158.

Wang H, Ng TB (2001b) Pleureryn, a novel protease from fresh fruiting bodies of the edible mushroom Pleurotus eryngii. Biochem Biophys Res Commun 289: 750-755.
Wang H, Ng TB (2003a) Isolation of a ribonuclease from fruiting bodies of the wild mushroom Termitomyces globulus. Peptides 24: 973-977.

Wang H, Ng TB (2003b) A ribonuclease with distinctive features from the wild green-headed mushroom Russulus virescens. Biochem Biophys Res Commun 312: 965-968.

Wang H, Ng TB (2004) Eryngin, a novel antifungal peptide from fruiting bodies of the edible mushroom Pleurotus eryngii. Peptides 25: 1-5.

Wang H, Ng TB, Liu Q (2002) Isolation of a new heterodimeric lectin with mitogenic activity from fruiting bodies of the mushroom Agrocybe cylindracea. Life Sci 70: 877-885.

Wang H, Ng TB, Liu Q (2003a) A novel lectin from the wild mushroom Polyporus adusta. Biochem Biophys Res Commun 307: 535-539.

Wang HX, Ng TB (2000a) Flammulin: a novel ribosome-inactivating protein from fruiting bodies of the winter mushroom Flammulina velutipes. Biochem Cell Biol 78: 699-702.

Wang HX, Ng TB (2000b) Isolation of a novel ubiquitin-like protein from Pleurotus ostreatus mushroom with anti-human immunodeficiency virus, translation-inhibitory, and ribonuclease activities. Biochem Biophys Res Commun 276: 587-593.

Wang HX, Ng TB (2001c) Purification and characterization of a potent homodimeric guanine-specific ribonuclease from fresh mushroom (Pleurotus tuber-regium) sclerotia. Int J Biochem Cell Biol 33: 483-490.

Wang HX, Ng TB, Liu WK, Ooi VE, Chang ST (1995) Isolation and characterization of two distinct lectins with antiproliferative activity from the cultured mycelium of the edible mushroom Tricholoma mongolicum. Int J Pept Protein Res 46: 508-513.

Wang HX, Ngai HK, Ng TB (2003b) A ubiquitin-like peptide with ribonuclease activity against various polyhomoribonucleotides from the yellow mushroom Cantharellus cibarius. Peptides 24: 509-513.

Wannet WJ, Op den Camp HJ, Wisselink HW, van der Drift C, Van Griensven LJ, Vogels GD (1998) Purification and characterization of trehalose phosphorylase from the commercial mushroom Agaricus bisporus. Biochim Biophys Acta 1425: 177-188.

Zhuang C, Murata T, Usui T, Kawagishi H, Kobayashi K (1996) Purification and characterization of a lectin from the toxic mushroom Amanita pantherina. Biochim Biophys Acta 1291: 40-44. 